\title{
TOMOGRAFIA SÍSIMICA COM ONDAS P E S PARA O ESTUDO DO MANTO SUPERIOR NO BRASIL
}

\author{
Marcelo Peres Rocha \\ Orientador: Dr. Marcelo Sousa de Assumpção (IAG/USP) \\ 86 p. - Tese (Doutorado) - Defesa 23.06.2008
}

RESUMO. Nós usamos tomografia sísmica de tempo de percurso para estudar o manto superior sob as regiões Sudeste e Centro-Oeste do Brasil. Este método baseia-se na inversão de resíduos relativos de tempo para as ondas P e S (VanDecar, 1991), que foram obtidos para mais de 80 estações em uma área de $20 \times 20$ graus. Mais de 11000 e 8000 resíduos de tempo foram obtidos para as ondas P (P direta e PKPdf) e S (S direta, ScS, SKS e SKKS), respectivamente, utilizando correlação cruzada de forma de ondas para até 12 estações operando simultaneamente. Para avaliar a robustez dos resultados com respeito aos dados, nós utilizamos o método estatístico de re-amostragem Jackknife, o qual inerentemente leva em conta a altamente variável cobertura dos raios e os erros das medidas, e pode fornecer limites de confiança para as anomalias. Inversões regionais foram realizadas para estudar a influência da parametrização nas anomalias sísmicas. Nossos resultados mostraram boa correlação das anomalias sísmicas com as principais estruturas tectônicas e revelaram novas anomalias que ainda não haviam sido observadas nos trabalhos anteriores. Anomalias de alta velocidade na porção oeste do Cráton do São Francisco apóiam a hipótese de que este cráton foi parte de uma placa Neoproterozóica maior. Anomalias de baixa velocidade sob a Província Tocantins (principalmente nas faixas móveis entre os Crátons Amazônico e do São Francisco) foram interpretadas como causadas por afinamento litosférico, consistente com a boa correlação entre a sismicidade intraplaca e as anomalias de baixa velocidade nesta região (Assumpção et al., 2004b). A melhora na resolução da anomalia de alta velocidade sob a Bacia do Paraná ( 200 km) permitiu uma discussão sobre a geometria do núcleo cratônico desta Bacia. A subducção da Placa de Nazca foi observada como uma anomalia de alta velocidade sob a Bacia do Paraná (profundidades entre 700 e $1200 \mathrm{~km}$ ). Nestas profundidades, uma grande anomalia de baixa velocidade aparece próxima da Placa de Nazca. Testes sintéticos mostraram que esta anomalia é um artefato da inversão gerado pela presença da Placa de Nazca.

ABSTRACT. We used travel time seismic tomography to study the upper mantle beneath SE and Central Brazil. This method is based on the inversion of P- and S-wave relative travel time residuals (VanDecar, 1991) obtained from more than 80 stations in an area of $20 \times 20$ degrees. More than $11000 \mathrm{P}$ and PKP residuals and more than $8000 \mathrm{~S}$, ScS, SKS, and SKKS residuals were obtained from waveform cross-correlations for up to 12 simultaneous stations. To evaluate the robustness of the tomographic results with respect to the data, we use the Jackknife re-sampling method, which inherently take into account the highly variable ray coverage and measurement errors, and can provide confidence limits for the anomalies. Regional inversions were carried out to study influence of the parameterization on the seismic anomalies. Our results show correlations of seismic anomalies with the main tectonic structures and reveal new anomalies not yet observed in previous works. High velocity anomalies in the western portion of the São Francisco Craton support the hypothesis that this craton was part of a major Neoproterozoic plate. Low velocity anomalies beneath the Tocantins Province (mainly fold belts between the Amazon and São Francisco Cratons) are interpreted as due to lithospheric thinning, consistent with a good correlation between intraplate seismicity and low velocity anomalies in this region (Assumpção et al., 2004b). The resolution improvement of the high velocity anomalies beneath the Paraná Basin (at $\sim 200 \mathrm{~km}$ ) allows a discussion about the geometry of the cratonic nucleus of this Basin. The slab of the Nazca Plate is observed as a high velocity anomaly beneath the Paraná Basin (at 700-1200 km depth). At these depths, large low velocity anomaly appears next to the slab. Synthetic tests show that these anomalies are an artifact of the inversion generated by the presence of the slab. 